\title{
Selenate Concentration Affects Selenium and Sulfur Uptake and Accumulation by 'Granex 33' Onions
}

\author{
Dean A. Kopsell ${ }^{1}$ and William M. Randle ${ }^{2}$ \\ Department of Horticulture, The University of Georgia, Athens, GA 30602
}

ADDITIONAL INDEX woRDs. depletion, leaf, bulb, and root tissues, antagonism

\begin{abstract}
ABSTRACr. Selenium and sulfur have similar chemical structures. This allows Se to be absorbed and incorporated in the same assimilation pathways as S. Onions (Allium cepa L.) are a crop with unique $S$ metabolism, responsible for growth and flavor intensity. Because of the antagonistic behavior of the two ions, the effects of Se on $S$ and Se nutrient depletion and tissue accumulation were investigated. 'Granex 33' onions were grown in nutrient solutions with one concentration of $\mathrm{S}$ and increasing Se concentrations. Selenium was applied as sodium selenate $\left(\mathrm{Na}_{2} \mathrm{SeO}_{4}\right)$ at concentrations of $0,0.5,1.0$, 1.5 , and $2.0 \mathrm{mg} \cdot \mathrm{L}^{-1}$. Selenium depletion from the nutrient solution increased linearly with increasing $\mathrm{Na}_{2} \mathrm{SeO}_{4}$ treatment concentrations. Sulfur depletion increased and then decreased with increasing $\mathrm{Na}_{2} \mathrm{SeO}_{4}$ treatment concentrations. Selenium and $S$ accumulation were highest in leaf tissues, less in root tissues, and lowest in bulb tissues at plant maturity. Selenium accumulation increased linearly with increasing $\mathrm{Na}_{2} \mathrm{SeO}_{4}$ for all tissues analyzed. Sulfur accumulation in leaf and bulb tissues was quadratic in response to increasing $\mathrm{SeO}_{4}{ }^{-2}$, while $\mathrm{S}$ in root tissues decreased linearly with increasing $\mathrm{Na}_{2} \mathrm{SeO}_{4}$. Low concentrations of $\mathrm{Na}_{2} \mathrm{SeO}_{4}$ in our study enhanced $\mathrm{S}$ uptake and accumulation. Previously, Se was thought to competitively inhibit $S$ uptake and metabolism.
\end{abstract}

Although Se is required in animal nutrition, it is not classified as an essential plant nutrient (Mayland et al., 1989). Plants take up Se according to the concentration, availability, form of Se present in the soil, and according to plant development and species (Trelease and Beath, 1949). Selenium and S have very similar chemical and physical properties (Combs and Combs, 1986). Selenate $\left(\mathrm{SeO}_{4}{ }^{-2}\right)$ uptake by plants is similar to the active absorption of sulfate $\left(\mathrm{SO}_{4}{ }^{-2}\right)$ (Bryant and Laishley, 1988; Shrift and Ulrich, 1969), and the two ions are proposed to compete for the same binding sites in plant roots. Selenate is more readily absorbed and evenly distributed in plants than selenite $\left(\mathrm{SeO}_{3}{ }^{-2}\right)$ (HurdKarrer, 1937; van Dorst and Peterson, 1984). Comparing the two forms of $\mathrm{Se}, \mathrm{SeO}_{4}{ }^{-2}$ was found to accumulate in concentrations far exceeding those of $\mathrm{SeO}_{3}{ }^{-2}$ in plants (Brown and Shrift, 1982). Vegetables grown on Se-enriched coal fly ash absorbed Se in proportion to the levels in fly ash applied to the soil (Furr et al., $1976,1978)$. Selenium accumulations were also proportional to total soil Se concentrations for rice (Oryza sativa L. 'M101') (Mikkelsen et al., 1989), milkvetch [Astragalus bisulcatus (Hook.) Gray], wheatgrass [Pascopyrum smithii (Rydb.) Löve] (Williams and Mayland, 1992), and wheat (Triticum aestivum L.) (Singh, 1994).

The highest concentrations of Se in plants are most often seen in active growing points (Kabata-Pendias and Pendias, 1992). Distribution of $\mathrm{SeO}_{4}^{-2}$ in Phaseolus vulgaris $\mathrm{L}$. favored the actively growing organs where $S$ protein synthesis was high (Arvy, 1993). In other studies, Se was highest in the leaves and lowest in the stems for alfalfa (Medicago sativa $\mathrm{L}$.), red clover (Trifolium pratense L.), broccoli (Brassica oleracea var. italica Plenck), brussels spouts (Brassica oleracea var. gemmifera Zenker), cauliflower (Brassica oleracea var. botrytis L.), and rutabaga (Brassica napobrassica Mill) (Gupta, 1991). Sulfur-accumulating vegetables, such as onions and members of the cabbage family, had

Received for publication 30 Oct. 1996. Accepted for publication $24 \mathrm{Feb}$. 1997. The cost of publishing this paper was defrayed in part by the payment of page charges. Under postal regulations, this paper therefore must be hereby marked advertisement solely to indicate this fact.

${ }^{1}$ Graduate assistant.

${ }^{2}$ Associate professor. higher levels of Se than other vegetable groups in Finland (Eurola et al., 1989). In a similar study, broccoli (Brassica oleracea var. Early One), onion (Allium cepa), and lettuce (Lactuca sativa) absorbed the highest concentrations of Se among the vegetables evaluated (Shane et al., 1988).

Sulfur can influence Se accumulation in plants. The addition of elemental S, $\mathrm{SO}_{4}^{-2}$, or gypsum reduced plant $\mathrm{SeO}_{4}{ }^{-2}$ uptake (HurdKarrer, 1938; Mikkelsen et al., 1989). Conversely, Se has the ability to replace $S$ in plant metabolism (Trelease et al., 1960). The similarity of Se analogues to corresponding $\mathrm{S}$ amino acids of cysteine and methionine, however, act to disrupt normal biochemical reactions (Mikkelsen et al., 1989). Therefore, plant Se toxicity results from an interference of normal S metabolism (Adriano, 1986; Mikkelsen et al., 1989; Shrift, 1954). In wheat, Se toxicity depended on the $\mathrm{S}$ content of the plants (Hurd-Karrer, 1938), and increasing $\mathrm{SO}_{4}^{-2}$ reduced the toxicity of $\mathrm{SeO}_{4}^{-2}$ (Trelease and Beath, 1949).

Hurd-Karrer (1938) proposed that crops with high S requirements have the potential to absorb Se in high amounts. Selenium accumulation has been documented in onion (Gutenmann and Lisk, 1996; Ip and Lisk, 1994; Ip et al., 1992). Onions have distinctive S metabolism (Landcaster and Boland, 1990), which supports plant growth and important secondary flavor compounds and is influenced by S fertility levels (Freeman and Mossadeghi, 1970; Randle, 1992; Randle et al., 1994). Onions are grown in areas of the United States on soils with elevated Se, such as the San Joaquin Valley of California. This experiment was under taken to 1) determine the absorption and accumulation patterns of $\mathrm{Se}$ during onion ontogeny, and 2) determine what effect Se concentration had on $\mathrm{S}$ absorption and accumulation by onions. In addition, it was our intent to determine how much Se onions could accumulate without severely affecting plant growth and development.

\section{Materials and Methods}

'Granex 33' onions were seeded into growing cubes (Grodan A/ S, Dk-2640 Hedehusene, Denmark) in September 1994. Three to four seeds were placed into each cell. The cells were filled with fine vermiculite and watered daily. Fertilization with a $200-\mathrm{mg} \cdot \mathrm{L}^{-1}$ solution of Peters 20N-20P-20K (Grace-Sierra Co., Milpitas, 
Table 1. Mean and standard deviation for total depletion of plant $\mathrm{S}$ and $\mathrm{Se}$ $\left(\mathrm{mg} \cdot \mathrm{d}^{-1}\right.$ ) by 'Granex 33 ' onions in response to increasing sodium selenate $\mathrm{Na}_{2} \mathrm{SeO}_{4}$ concentrations in nutrient solutions. Values are means of four replications averaged over six sampling dates.

\begin{tabular}{|c|c|c|}
\hline $\mathrm{Na}_{2} \mathrm{SeO}_{4}\left(\mathrm{mg} \cdot \mathrm{L}^{-1}\right)$ & Selenium & Sulfur \\
\hline 0 & $\mathrm{ND}^{z}$ & $180.0 \pm 130.7$ \\
\hline 0.5 & $2.26 \pm 1.90$ & $245.0 \pm 171.2$ \\
\hline 1.0 & $4.93 \pm 4.55$ & $234.6 \pm 187.3$ \\
\hline 1.5 & $6.83 \pm 5.24$ & $235.0 \pm 144.9$ \\
\hline 2.0 & $8.79 \pm 6.60$ & $187.9 \pm 126.4$ \\
\hline \multicolumn{3}{|l|}{ Contrast } \\
\hline Linear & $P=0.0001$ & NS \\
\hline Quadratic & NS & $P=0.076$ \\
\hline
\end{tabular}

2ND $=$ not detected

ss Nonsignificant.

Calif.) was applied as needed once seedlings emerged. Seedlings were thinned to one plant per cell 3 weeks after sowing. The seedlings were greenhouse grown $\left(25^{\circ} \mathrm{C}\right.$ day and $20^{\circ} \mathrm{C}$ night $)$ for 2 additional weeks under natural photoperiods ( $\approx 34^{\circ} \mathrm{N}$ latitude). A broad-spectrum fungicide (Bravo 720; Fermenta Plant Protection Co., Mentor, Ohio) was applied as needed.

On 21 Oct. 1994, plants were transferred to 37.9-L containers (Rubbermaid Inc., Wooster, $\mathrm{OH}$ ). Fifteen plants were placed in $2.22-\mathrm{cm}$ holes at $10.6 \times 9.5-\mathrm{cm}$ spacings on each container lid. The containers were filled with $30 \mathrm{~L}$ of a half-strength modified Hoagland's solution (Hoagland and Arnon, 1950). The $\mathrm{MgSO}_{4} \cdot 7 \mathrm{H}_{2} \mathrm{O}$ concentration was $493 \mathrm{mg} \cdot \mathrm{L}^{-1}\left(192.3 \mathrm{mg} \cdot \mathrm{L}^{-1}\right)$ on a $\mathrm{SO}_{4}^{-2}$ basis. The nutrient solutions were aerated via nalgene tubing attached to a commercial air compressor. Wire mesh was attached to each container lid at a height of $20 \mathrm{~cm}$ to support plant foliage. Each solution was replaced every 2 weeks throughout the experiment to refresh the solutions to the initial nutrient concentrations.

On 23 Nov. 1994, five $\mathrm{Na}_{2} \mathrm{SeO}_{4}$ (ICN Biochemicals, Cleveland) treatments were initiated. The $\mathrm{Na}_{2} \mathrm{SeO}_{4}$ treatment concentrations were $0,0.5,1.0,1.5$, and $2.0 \mathrm{mg} \cdot \mathrm{L}^{-1}$ of nutrient solution. Preliminary tests at $\mathrm{Na}_{2} \mathrm{SeO}_{4}$ concentrations $>2.0 \mathrm{mg} \cdot \mathrm{L}^{-1}$ with $\mathrm{SO}_{4}^{-2}$ concentrations at $9.6 \mathrm{mg} \cdot \mathrm{L}^{-1}$ resulted in severe growth reduction or plant death. Each treatment was replicated four times. The experimental design was a split plot, with $\mathrm{Na}_{2} \mathrm{SeO}_{4}$ treatments as the main plots and sampling dates as the subplots. To initiate onion maturation, the bulbing process was begun through artificial extension of the natural photoperiod. On 7 Dec. 1994, the natural photoperiod was extended to $11 \mathrm{~h}$ using incandescent 75-W lighting (18 $\mathrm{mmol} \cdot \mathrm{m}^{-1} \cdot \mathrm{s}^{-1}$ ). The lights were suspended over the tubs at a height of $1 \mathrm{~m}$. The photoperiod was extended an additional $1 \mathrm{~h}$ at 2 -week intervals until a 13-h photoperiod was reached. The 13-h photoperiod was maintained to the end of the experiment and was sufficient to complete the bulbing process and plant maturation.

To measure Se and S depletion during each 2-week period, 20 $\mathrm{mL}$ solution samples were taken from each container before and after each complete solution change. Solution samples were filtered through Whatman no. 1 filter paper (Maidstone, England). Solution Se was determined by graphite furnace atomic absorption spectrophotometry (GFAA) (model 4100ZL; Perkin-Elmer Corp., Norwalk, Conn.). The detection limit for Se by GFAA was 0.004 $\mathrm{mg} \cdot \mathrm{L}^{-1}$. Sulfate depletion was quantified using a turbidimetric method developed by Gains and Mitchell (1979). Nutrient depletion for the 2-week period was determined by subtracting final sample values from the initial sample. Values are reported on a per plant basis.

Plant tissue sampling began 2 weeks after $\mathrm{Na}_{2} \mathrm{SeO}_{4}$ addition on
7 Dec. 1994 and was continued at each 2-week solution change. Two plants were taken at random from each replication. Plants were rinsed once in deionized water to remove any surface contamination. The plants were combined and divided into root, pseudostem (bulb), and leaf tissues. Each tissue was placed into a paper bag and allowed to dry at $60^{\circ} \mathrm{C}$ in a forced air drying oven (model 630; National Appliance Co., Portland, Oreg.) for no less than $48 \mathrm{~h}$. The dried tissue was then ground to pass through a $0.5-$ $\mathrm{mm}$ screen in a cyclotec sample mill grinder (model 1093; Tector, Höganäs, Sweden).

A wet acid digest was used for Se analysis. One gram of the onion powder sample was placed into a $125-\mathrm{mL}$ flask with $10 \mathrm{~mL}$ of concentrated nitric acid and placed on a hot plate (type 2200; Thermolyne, Dubuque, Iowa) for $4 \mathrm{~h}$ at $165^{\circ} \mathrm{C}$. The flasks were allowed to cool to room temp and brought to a final volume of 50 $\mathrm{mL}$ with deionized water. The solutions were filtered through Whatman no. 1 filter paper. Total Se was measured by GFAA
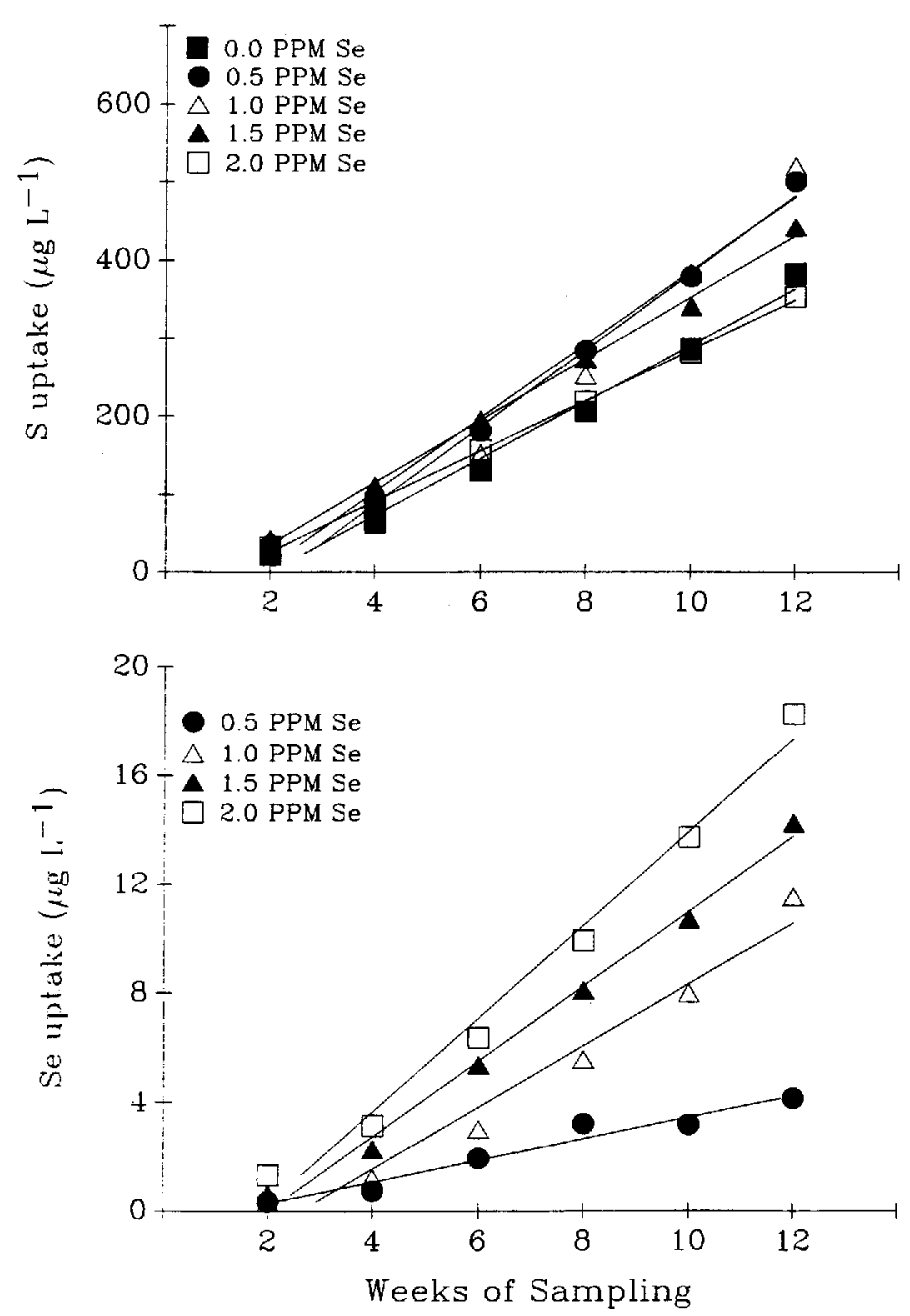

Fig. 1. Sulfur and selenium uptake (per plant per day) of 'Granex 33' onion responding to increasing sodium selenate fertility when greenhouse grown to maturity in nutrient solutions. Solutions were sampled every 2 weeks. Selenium uptake in response to $0.5,1.0,1.5$, and $2.0 \mathrm{mg} \cdot \mathrm{L}^{-1} \mathrm{Na}_{2} \mathrm{SeO}_{4}$ of solution is described by $\mathrm{Y}=-0.505+0.790$ (Date), $r^{2}=0.53$, standard error of estimate (SEE) $=0.160$; $\mathrm{Y}=-2.964+2.256$ (Date), $r^{2}=0.75$, SEE $=0.278 ; \mathrm{Y}=-2.824+2.759$ (Date),$r^{2}$ $=0.84, \mathrm{SEE}=0.253 ;$ and $\mathrm{Y}=-3.206+3.427$ (Date) $, r^{2}=0.82, \mathrm{sEE}=0.341$, respectively. Sulfur uptake in response to $0.0,0.5,1.0,1.5$, and $2.0 \mathrm{mg} \cdot \mathrm{L}^{-1}$ $\mathrm{Na}_{2} \mathrm{SeO}_{4}$ of solution is described by $\mathrm{Y}=-72+73$ (Date), $r^{2}=0.94$, $\mathrm{SEE}=0.004$; $\mathrm{Y}=-84+93$ (Date) $, r^{2}=0.92, \operatorname{sEE}=0.006 ; \mathrm{Y}=-117+101$ (Date), $r^{2}=0.88$, sEF $=0.008 ; \mathrm{Y}=-44+80\left(\right.$ Date),$r^{2}=0.92$, SEE $=0.005$; and $\mathrm{Y}=-40+65$ (Date), $r^{2}$ $=0.81, \mathrm{SEE}=0.007$, respectively. 
spectrophotometry. Total $\mathrm{S}$ in the plant tissue samples was determined using a S determinator (model SC-232; Leco, St. Joseph, Mich.). One gram of onion powder was combined with vanadium pentoxide (Leco) accelerator and combusted at $1371^{\circ} \mathrm{C}$ with $\mathrm{O}_{2}$. Total $\mathrm{S}$ was measured as $\mathrm{SO}_{2}$ with an infrared cell detector.

Data were analyzed by the GLM procedure of SAS (Cary, N.C.). The relationship among Se or $\mathrm{S}$ depletion and Se treatment or sample date were determined by regression analysis. Differences among the regression equations were tested using simple $t$ testing. Orthogonal polynomials were used to study changes associated with increasing $\mathrm{Na}_{2} \mathrm{SeO}_{4}$ concentrations by partitioning the sums of squares into components that were associated with linear, quadratic, or cubic terms (Steel and Torrie, 1980).

\section{Results and Discussion}

High Se concentrations in the nutrient solution had a visible effect on onion plant growth. At the $2.0-\mathrm{mg} \cdot \mathrm{L}^{-1} \mathrm{Na}_{2} \mathrm{SeO}_{4}$ concentration, onion foliage was visibly shorter, bulb size was smaller, and root mass was much reduced compared to the $0-\mathrm{mg} \cdot \mathrm{L}^{-1}$ $\mathrm{Na}_{2} \mathrm{SeO}_{4}$ treatment. In a preliminary experiment with $\mathrm{SO}_{4}^{-2}$ levels at $9.6 \mathrm{mg} \cdot \mathrm{L}^{-1}, \mathrm{Na}_{2} \mathrm{SeO}_{4}$ at $4.0 \mathrm{mg} \cdot \mathrm{L}^{-1}$ resulted in onion death within 6 weeks. Decreases in plant growth and yield with increased Se application were also reported for alfalfa (Medicago sativa $\mathrm{L}$. var. African) and subterranean clover (Trifolium subterraneum $\mathrm{L}$. var. Mt. Baker) (Broyer et al., 1966).

SE DEPLETION FROM NUTRIENT SOLUTIONS. Selenium depletion from the nutrient solution by the onions responded significantly to the $\mathrm{Na}_{2} \mathrm{SeO}_{4}$ concentration $(\mathrm{F}=100.0 ; P=0.0001)$, the date of sample collection $(\mathrm{F}=82.1 ; P=0.0001)$, and the interaction of concentration and date $(\mathrm{F}=9.8 ; P=0.0001)$. Total Se depletion per plant per day increased linearly with increasing $\mathrm{Na}_{2} \mathrm{SeO}_{4}$ concentration $(P=0.01$; Table 1$)$. Selenium in the nutrient solutions at the 0 -mg. $\mathrm{L}^{-1} \mathrm{Na}_{2} \mathrm{SeO}_{4}$ treatment were below detection limits by GFAA. As plants grew, developed, and matured during the course of the experiment, there were significant linear increases in Se depletion over time at each of the $\mathrm{Na}_{2} \mathrm{SeO}_{4}$ concentrations (Fig. 1). The slope for Se depletion at the 2.0-mg. $\mathrm{L}^{-1} \mathrm{Na}_{2} \mathrm{SeO}_{4}$ was greatest and statistically different from the slopes of all other $\mathrm{Na}_{2} \mathrm{SeO}_{4}$ concentrations. Conversely, the slope for Se depletion at the $0.5-\mathrm{mg} \cdot \mathrm{L}^{-1}$ $\mathrm{Na}_{2} \mathrm{SeO}_{4}$ was least and statistically different from the slopes of all other $\mathrm{Na}_{2} \mathrm{SeO}_{4}$ concentrations. Increased Se uptake with increasing plant age was consistent with previous finding for wheat (Triticum aestivum.) (Singh, 1994), rice (Oryza sativa 'M101') (Mikkelsen et al., 1989), and other vegetable crops (Furr et al., 1976, 1978).

Sulfate depletion by the onions also responded significantly to the $\mathrm{Na}_{2} \mathrm{SeO}_{4}$ concentrations $(\mathrm{F}=19.6 ; P=0.0001)$, the date of sample collection $(\mathrm{F}=457.9 ; P=0.0001)$, and the interaction of concentration and date $(\mathrm{F}=3.43 ; P=0.0001)$. Total $\mathrm{SO}_{4}{ }^{-2}$ depletion per plant per day averaged over dates was quadratic in response to increasing $\mathrm{Na}_{2} \mathrm{SeO}_{4}$ concentrations $(P=0.076$; Table 1). It was interesting to note that, while $\mathrm{SO}_{4}^{-2}$ concentrations did not change among the different $\mathrm{Na}_{2} \mathrm{SeO}_{4}$ concentrations, there was an increase in $\mathrm{SO}_{4}{ }^{-2}$ depletion in the nutrient solutions by the onions, indicating greater $\mathrm{SO}_{4}{ }^{-2}$ use as $\mathrm{Na}_{2} \mathrm{SeO}_{4}$ concentrations increased. Previously, Se was thought to depress $\mathrm{SO}_{4}{ }^{-2}$ absorption and transport (Ferrari and Renosto, 1972; Leggett and Epstein, 1956). At each $\mathrm{Na}_{2} \mathrm{SeO}_{4}$ concentration, $\mathrm{SO}_{4}^{-2}$ depletion from nutrient solutions linearly increased as plants grew and matured (Fig. 1). The slope for $\mathrm{SO}_{4}^{-2}$ depletion at the $1.0 \mathrm{mg} \cdot \mathrm{L}^{-1} \mathrm{Na}_{2} \mathrm{SeO}_{4}$ concentration was greatest and statistically different from the slopes of all other $\mathrm{Na}_{2} \mathrm{SeO}_{4}$ concentrations. Conversely, the slope for $\mathrm{SO}_{4}{ }^{-2}$ depletion at the $2.0 \mathrm{mg} \cdot \mathrm{L}^{-1} \mathrm{Na}_{2} \mathrm{SeO}_{4}$ concentration was least and statistically different from the slopes of all other $\mathrm{Na}_{2} \mathrm{SeO}_{4}$ concentrations

The onions depleted Se from the nutrient solutions in relative proportion to the concentration of $\mathrm{Na}_{2} \mathrm{SeO}_{4}$ in the current study. The higher the Se concentration, the greater Se depletion by the onions. Shrift and Ulrich (1969) suggested that $\mathrm{SO}_{4}^{-2}$ and $\mathrm{SeO}_{4}{ }^{-2}$ may be in direct competition for $\mathrm{S}$ permease binding. Selenium analogues can replace their respective S-amino acids found in normal plant metabolism. The high amount of Se absorbed may have interrupted normal S metabolism through replacement of S

Table 2. Mean total selenium and sulfur concentrations (dry mass basis) and standard deviations from leaf, bulb, and root tissues for the onion cultivar 'Granex 33' grown in nutrient solutions with increasing $\mathrm{Na}_{2} \mathrm{SeO}_{4}$. Values are means of four replications averaged over six sampling dates.

\begin{tabular}{|c|c|c|c|}
\hline \multirow{2}{*}{$\begin{array}{l}\mathrm{Na}_{2} \mathrm{SeO}_{4} \\
\left(\mathrm{mg} \cdot \mathrm{L}^{-1}\right) \\
\end{array}$} & \multicolumn{3}{|c|}{ Mean accumulation $\left(\mu \mathrm{g} \cdot \mathrm{g}^{-1}\right)$} \\
\hline & Leaf & Bulb & Root \\
\hline & & Selenium & \\
\hline 0 & $\mathrm{ND}^{2}$ & ND & ND \\
\hline 0.5 & $47.3 \pm 14.3$ & $18.9 \pm 6.1$ & $37.7 \pm 16.7$ \\
\hline 1.0 & $109.3 \pm 31.3$ & $41.4 \pm 11.7$ & $78.9 \pm 33.5$ \\
\hline 1.5 & $140.3 \pm 40.7$ & $56.5 \pm 25.9$ & $104.3 \pm 27.4$ \\
\hline 2.0 & $208.4 \pm 66.8$ & $70.9 \pm 19.6$ & $148.5 \pm 47.5$ \\
\hline \multicolumn{4}{|l|}{ Contrast } \\
\hline Linear & $P=0.0001$ & $\begin{array}{c}P=0.0001 \\
\text { Sulfur }^{\mathrm{y}}\end{array}$ & $P=0.0001$ \\
\hline 0 & $8204 \pm 1118$ & $4869 \pm 538$ & $10146 \pm 1121$ \\
\hline 0.5 & $11000 \pm 1792$ & $5806 \pm 1054$ & $8873 \pm 1230$ \\
\hline 1.0 & $12214 \pm 2129$ & $5888 \pm 1127$ & $9473 \pm 1488$ \\
\hline 1.5 & $11343 \pm 1668$ & $5425 \pm 1520$ & $7980 \pm 1458$ \\
\hline 2.0 & $11862 \pm 1816$ & $5025 \pm 1113$ & $8020 \pm 1643$ \\
\hline \multicolumn{4}{|l|}{ Contrast } \\
\hline Linear & $P=0.0001$ & NS & $P=0.0003$ \\
\hline Quadratic & $P=0.0001$ & $P=0.003$ & NS \\
\hline
\end{tabular}

${ }^{\mathrm{x}} \mathrm{ND}=$ not detected.

yThe models for Bulb S and Root S did not include the first two sampling dates due to insufficient tissue for analysis.

NSNonsignificant. 
proteins by Se-amino acids, producing a toxic effect. This could explain the visible reduction in foliar mass that was observed under the highest Se treatments. It may also explain the decrease in $\mathrm{SO}_{4}{ }^{-2}$ uptake for the high Se treatment. Therefore, if onions are grown in the presence of Se in soil solution, the concentration of Se may be one of the factors that dictate the absorption of Se and $\mathrm{SO}_{4}{ }^{-2}$.

SE and S accumulation in onion tissues. Selenium was unevenly distributed among the onion tissues analyzed. At each $\mathrm{Na}_{2} \mathrm{SeO}_{4}$ concentration, $\mathrm{Se}$ concentrations were highest in onion leaf tissues, intermediate in root tissues, and lowest in bulb tissues (Table 2). There was about a 3-fold difference in leaf Se concentration compared to bulb $\mathrm{Se}$ at each of the $\mathrm{Na}_{2} \mathrm{SeO}_{4}$ concentrations. Our findings were consistent with those of Gupta (1991), who reported that the highest Se concentrations were in leaf tissues for
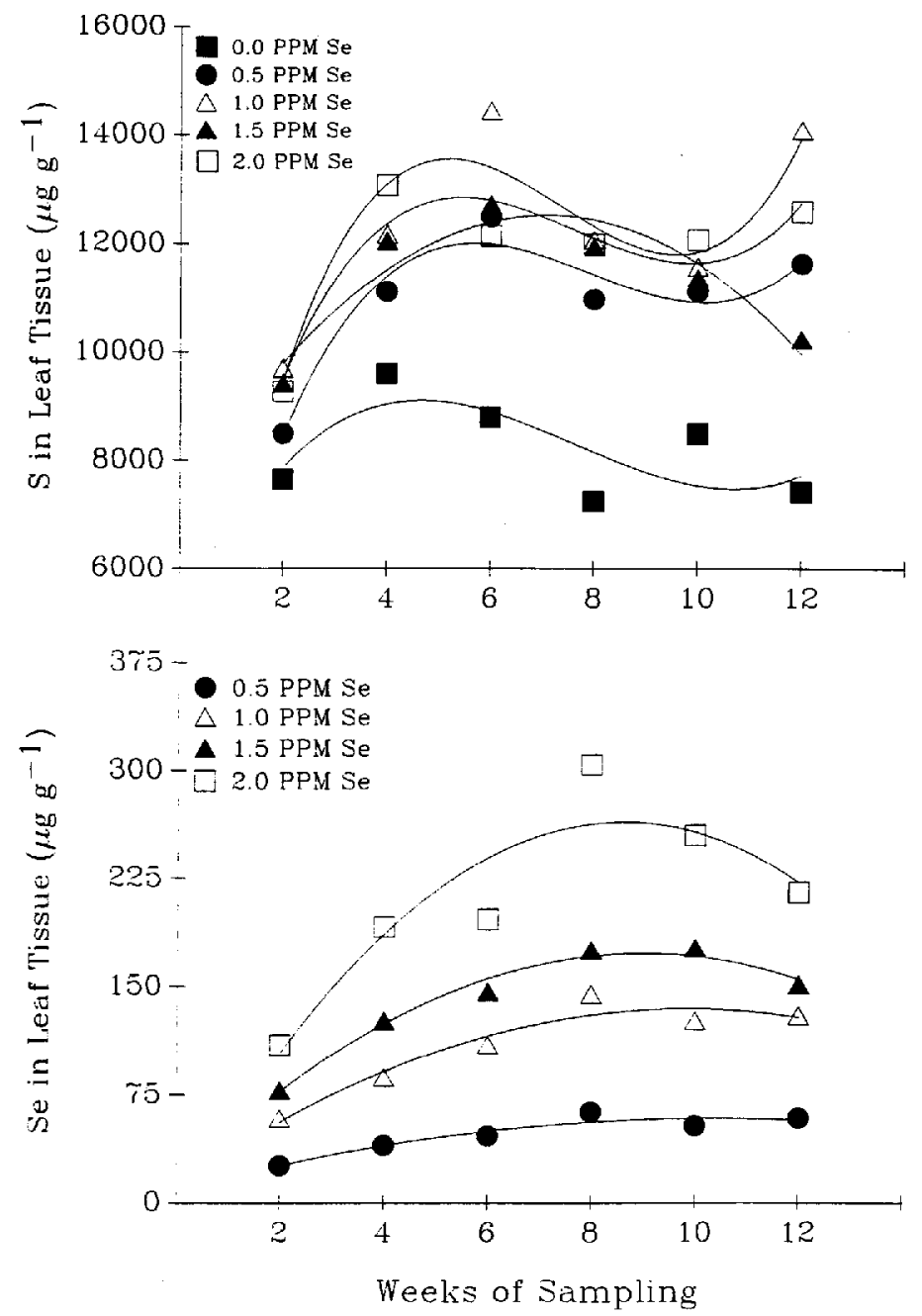

Fig. 2. Sulfur and selenium concentration, dry mass basis (mg. $\left.\mathrm{g}^{-1}\right)$ in the leaf tissue of 'Granex 33' onion responding to increasing sodium selenate fertility when greenhouse grown to maturity in nutrient solutions. Leaf tissue was sampled every 2 weeks. Selenium concentration in response to $0.5,1.0,1.5$, and $2.0 \mathrm{mg} \cdot \mathrm{L}^{-1}$ $\mathrm{Na}_{2} \mathrm{SeO}_{4}$ in solution is described by $\mathrm{Y}=7.796+19.743$ (Date) $-1.1924\left(\right.$ Date $\left.^{2}\right)$, $r^{2}=0.72$, standard error of estimate (SEE) $=0.685 ; \mathrm{Y}=10.173+50.621$ (Date) 5.146(Date $\left.)^{2}\right), r^{2}=0.84$, SEE $=1.072 ; \mathrm{Y}=15.022+69.792($ Date $)-7.718\left(\right.$ Date $\left.^{2}\right)$, $r^{2}=0.72, \mathrm{SEE}=1.973$; and $\mathrm{Y}=-1.104+119.561($ Date $)-13.668\left(\right.$ Date $\left.^{2}\right), r^{2}=0.72$, $\mathrm{SEE}=3.264$, respectively. Sulfur concentration in response to $0.0,0.5,1.0,1.5$, and $2.0 \mathrm{mg} \cdot \mathrm{L}^{-1} \mathrm{Na}_{2} \mathrm{SeO}_{4}$ in solution is described by $\mathrm{Y}=0.467+0.444$ (Date) $0.137\left(\right.$ Date $\left.^{2}\right)+0.012\left(\right.$ Date $\left.^{3}\right), r^{2}=0.28, \operatorname{SEE}=0.006 ; \mathrm{Y}=0.059+1.06($ Date $)-$ $0.311\left(\right.$ Date $\left.^{2}\right)+0.028\left(\right.$ Date $\left.^{3}\right), r^{2}=0.57, \operatorname{sEE}=0.008 ; \mathrm{Y}=0.032+1.259($ Date $)-$ $0.38\left(\right.$ Date $\left.^{2}\right)+0.035\left(\right.$ Date $\left.^{3}\right), r^{2}=0.54$, SEE $=0.010 ; \mathrm{Y}=0.696+0.329$ (Date) $0.047\left(\right.$ Date $\left.^{2}\right), r^{2}=0.51, \mathrm{SEE}=0.010$; and $\mathrm{Y}=0.139+1.102$ (Date) -0.322 (Date $\left.{ }^{2}\right)$ $+0.028\left(\right.$ Date $\left.^{3}\right), r^{2}=0.53$, SEE $=0.009$, respectively. several forage and vegetable crops, and with Hurd-Karrer (1937), who reported on $\mathrm{SeO}_{4}^{-2}$ distribution in wheat. Mean total Se accumulations across dates in all onion tissues linearly increased in response to increasing $\mathrm{Na}_{2} \mathrm{SeO}_{4}$ concentration $(P=0.01$; Table 2). Selenium concentrations for all tissues, however, were below detection limits by GFAA for $0 \mathrm{mg} \cdot \mathrm{L}^{-1} \mathrm{Na}_{2} \mathrm{SeO}_{4}$. Maximum $\mathrm{Se}$ accumulation at $2.0 \mathrm{mg} \cdot \mathrm{L}^{-1} \mathrm{Na}_{2} \mathrm{SeO}_{4}$ was $208.4,70.9$, and 148.5 $\mu \mathrm{g} \cdot \mathrm{g}^{-1}$, dry mass basis, for the leaf, bulb, and root tissue, respectively. Previously, the maximum Se concentration in onion bulb tissue was $28 \mu \mathrm{g} \cdot \mathrm{g}^{-1}$ when plants were grown in the soil and fertilized with sodium selenite $\left(\mathrm{Na}_{2} \mathrm{SeO}_{3}\right)$ and selenate $\left(\mathrm{Na}_{2} \mathrm{SeO}_{4}\right)$ (Ip and Lisk, 1994).

Selenium concentrations in leaf tissues differed in response to
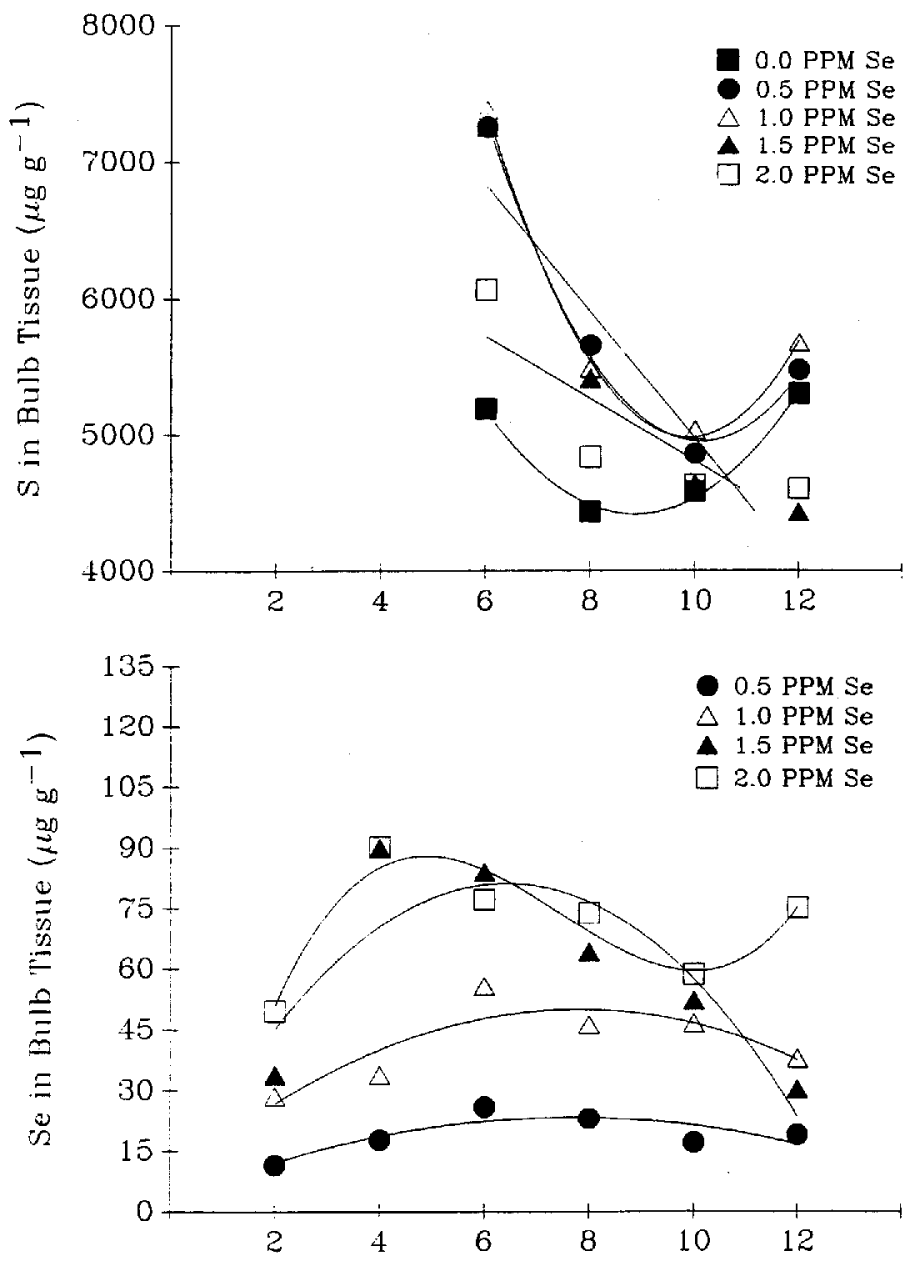

Weeks of Sampling

Fig. 3. Sulfur and selenium concentration, dry mass basis $\left(\mathrm{mg}^{-1} \mathrm{~g}^{-1}\right)$ in the bulb tissue of 'Granex 33' onion responding to increasing sodium selenate fertility when greenhouse grown to maturity in nutrient solutions. Bulb tissue was sampled every 2 weeks. Selenium concentration in response to $0.5,1.0,1.5$, and $2.0 \mathrm{mg} \cdot \mathrm{L}^{-1}$ $\mathrm{Na}_{2} \mathrm{SeO}_{4}$ in solution is described by $\mathrm{Y}=2.483+10.996$ (Date) $-1.458\left(\right.$ Date $\left.^{2}\right), r^{2}$ $=0.43$, standard error of estimate $(\mathrm{SEE})=0.412 ; \mathrm{Y}=7.899+21.601$ (Date) 2.776( Date $\left.^{2}\right), r^{2}=0.47, \mathrm{SEE}=0.731 ; \mathrm{Y}=-69.665+140.717$ (Date) $-38.208\left(\right.$ Date $\left.^{2}\right)$ $+2.932\left(\right.$ Date $\left.^{3}\right), r^{2}=0.72$, SEE $=0.979$; and $\mathrm{Y}=-40.630+126.252$ (Date) 38.327( Date $\left.^{2}\right)+3.417\left(\right.$ Date $\left.^{3}\right), r^{2}=0.45$, SEE $=1.025$, respectively. Sulfur concentration in response to $0.0,0.5,1.0,1.5$, and $2.0 \mathrm{mg} \cdot \mathrm{L}^{-1} \mathrm{Na}_{2} \mathrm{SeO}_{4}$ in solution is described by $\mathrm{Y}=11639-3266.25$ (Date) $+368.75\left(\right.$ Date $\left.^{2}\right), r^{2}=0.51$, sEE $=$ 100.566; $\mathrm{Y}=19131-5618.75$ (Date) $+556.25\left(\right.$ Date $\left.^{2}\right), r^{2}=0.75$, SEE $=142.026$; $\mathrm{Y}=20498-6292.50$ (Date) $+637.50\left(\right.$ Date $\left.^{2}\right), r^{2}=0.66, \mathrm{SEE}=175.336 ; \mathrm{Y}=9587.50$ -952 (Date), $r^{2}=0.49$, sEE $=250.410$; and $Y=7072.50-455$ (Date), $r^{2}=0.22$, SEE $=227.011$, respectively. The first two sampling dates were dropped due to insufficient tissue. 
$\mathrm{Na}_{2} \mathrm{SeO}_{4}$ concentration $(\mathrm{F}=490.8 ; P=0.0001)$, the date of sample collection $(\mathrm{F}=51.6 ; P=0.0001)$, and the interaction of $\mathrm{Na}_{2} \mathrm{SeO}_{4}$ concentration and date $(\mathrm{F}=8.37 ; P=0.0001)$. At each $\mathrm{Na}_{2} \mathrm{SeO}_{4}$ concentration, except for $0 \mathrm{mg} \cdot \mathrm{L}^{-1}$, significant quadratic trends for leaf Se concentration occurred as plants grew and matured (Fig. 2). The patterns of leaf Se accumulation were similar to those for leaf $S$ accumulation when onions were grown at high $S$ fertility (Randle et al., 1993). Leaf $S$ increased in concentration as plants grew in a nonbulbing photoperiod, but leaf $\mathrm{S}$ gradually decreased as plants bulbed and matured with extended day lengths. In our study, bulbing was visible with most plants at the eighth week of plant sampling. Since $\mathrm{SeO}_{4}{ }^{-2}$ is translocated mainly in an acropetal direction, like $\mathrm{SO}_{4}^{-2}$, the decrease in Se leaf concentration at the eighth week was probably associated with the basipetal movement of organic Se compounds. Onions and garlic have the ability to
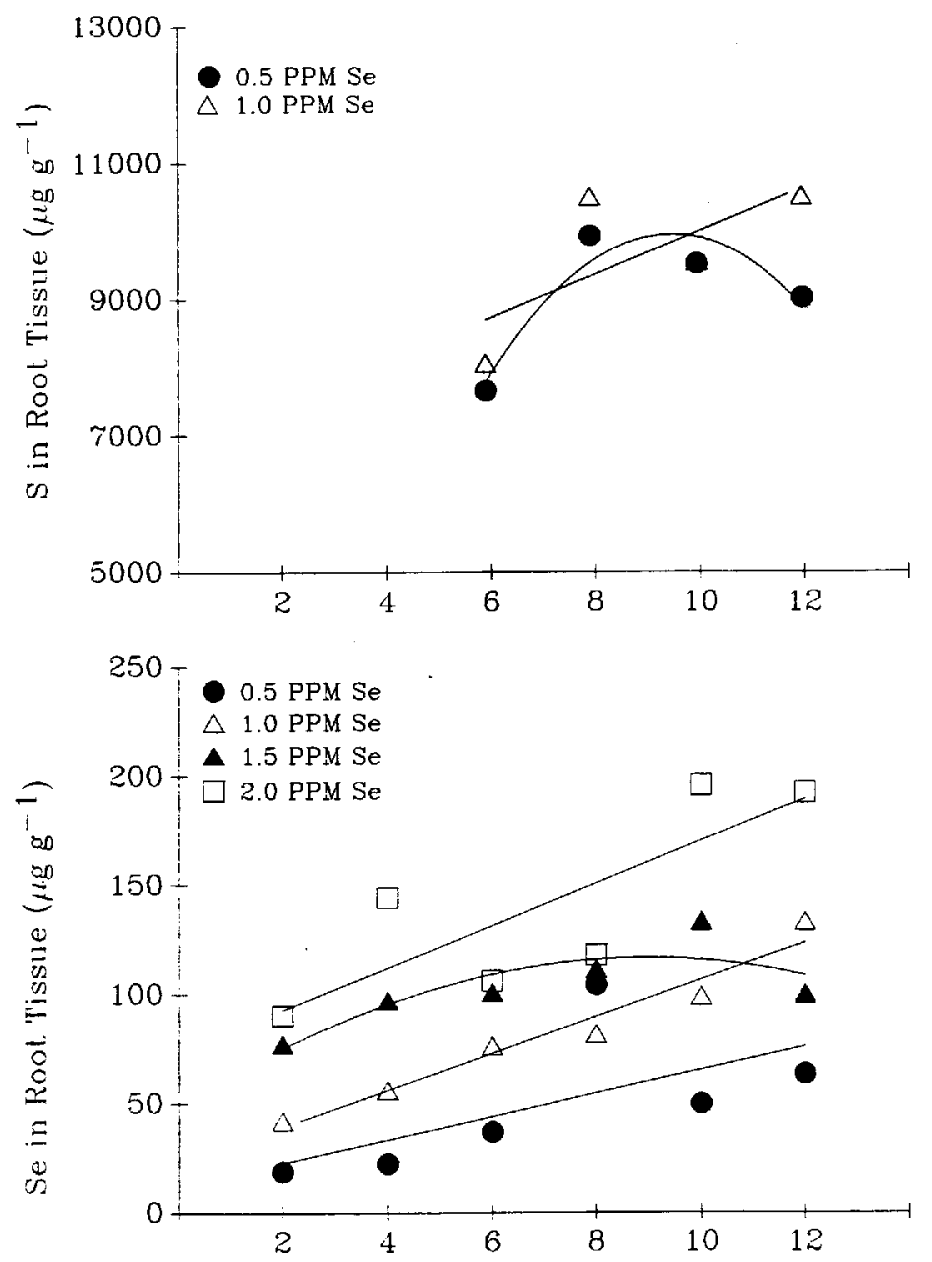

Weeks of Sampling

Fig. 4. Sulfur and selenium concentration, dry mass basis $\left(\mathrm{mg} \cdot \mathrm{g}^{-1}\right)$, in the root tiscue of 'Granex 33' onion responding to increasing sodium selenate fertility when greenhouse grown to maturity in nutrient solutions. Root tissue was sampled every 2 weeks. Selenium concentration in response to $0.5,1.0,1.5$, and $2.0 \mathrm{mg} \cdot \mathrm{L}^{-1}$ $\mathrm{Na}_{2} \mathrm{SeO}_{4}$ in solution is described by $\mathrm{Y}=8.409+8.531$ (Date), $r^{2}=0.80$, standard error of estimate $(\mathrm{SEE})=0.989 ; \mathrm{Y}=23.184+16.445$ (Date) $, r^{2}=0.70, \mathrm{SEE}=2.370$; $\mathrm{Y}=46.507+31.447$ (Date) $-3.529\left(\right.$ Date $\left.^{2}\right), r^{2}=0.25$, SEE $=2.126 ;$ and $\mathrm{Y}=84.902$ +18.306 (Date), $r^{2}=0.49, \operatorname{sEE}=4.327$, respectively. Sulfur concentration in response to 0.5 and $1.0 \mathrm{mg} \cdot \mathrm{L}^{-1} \mathrm{Na}_{2} \mathrm{SeO}_{4}$ in solution is described by $\mathrm{Y}=-5252.174$ $+6253.623($ Date $)-655.072\left(\right.$ Date $\left.^{2}\right), r^{2}=0.43$, sEE $=258.709 ; \mathrm{Y}=6107.865+$ 711.798 (Date), $r^{2}=0.37$, SEE $=309.418$, respectively. The regression equations for the treatments of $0.0,1.5$, and $2.0 \mathrm{mg} \cdot \mathrm{L}^{-1} \mathrm{Na}_{2} \mathrm{SeO}_{4}$ were not significant. The first two sampling dates were dropped due to insufficient tissue. incorporate Se into the S-based flavor pathway (Cai et al., 1995). Sulfur compounds associated with onion flavor are thought to be mainly synthesized in the leaves and translocated to expanding leaf bases during bulbing (Landcaster and Boland, 1990).

Selenium concentrations in bulb tissues differed in response to $\mathrm{Na}_{2} \mathrm{SeO}_{4}$ concentration $(\mathrm{F}=184.2 ; P=0.0001)$, the date tissues were collected $(\mathrm{F}=12.93 ; P=0.0001)$, and the interaction of $\mathrm{Na}_{2} \mathrm{SeO}_{4}$ concentration and date $(\mathrm{F}=4.39 ; P=0.0001)$. Plants grown with no $\mathrm{Na}_{2} \mathrm{SeO}_{4}$ had bulb Se concentrations below detection limits by GFAA. Mean bulb Se concentration in response to tissue collection dates resulted in significant quadratic trends at $0.5,1.0$, and $1.5 \mathrm{mg} \cdot \mathrm{L}^{-1} \mathrm{Na}_{2} \mathrm{SeO}_{4}$ (Fig. 3). At the $2.0-\mathrm{mg} \cdot \mathrm{L}^{-1}$ $\mathrm{Na}_{2} \mathrm{SeO}_{4}$ concentration, a significant cubic response was detected as plants grew and matured.

Root tissue Se concentrations differed in response to $\mathrm{Na}_{2} \mathrm{SeO}_{4}$ concentration $(\mathrm{F}=202.3 ; P=0.0001)$, the date tissues were collected $(\mathrm{F}=19.2 ; P=0.0001)$, and the interaction of $\mathrm{Na}_{2} \mathrm{SeO}_{4}$ concentration and date $(\mathrm{F}=3.74 ; P=0.0001)$. Plants grown with no $\mathrm{Na}_{2} \mathrm{SeO}_{4}$ had root Se concentrations below detection limits by GFAA. Mean root Se concentration in response to tissue collection dates resulted in significant linear trends at $0.5,1.0$, and $1.5 \mathrm{mg} \cdot \mathrm{L}^{-1} \mathrm{Na}_{2} \mathrm{SeO}_{4}$ (Fig. 4). At the $2.0-\mathrm{mg} \cdot \mathrm{L}^{-1} \mathrm{Na}_{2} \mathrm{SeO}_{4}$ concentration, a significant quadratic response was detected as plants grew and matured.

Sulfur, like Se, was unevenly distributed among the onion tissues sampled but was within the range previously reported for onion tissues (Randle, 1992; Randle et al., 1993). Total S concentrations were highest in the leaves, intermediate in root tissue, and lowest in the bulb tissue across $\mathrm{Na}_{2} \mathrm{SeO}_{4}$ concentrations and tissue collection dates (Table 2). Leaf $S$ concentrations were about double the bulb $\mathrm{S}$ concentrations at each of the $\mathrm{Na}_{2} \mathrm{SeO}_{4}$ treatments. Leaf $\mathrm{S}$ concentrations had linear and quadratic responses to increasing $\mathrm{Na}_{2} \mathrm{SeO}_{4}$, bulb $\mathrm{S}$ had a quadratic response to increasing $\mathrm{Na}_{2} \mathrm{SeO}_{4}$ concentrations in the nutrient solutions, and root $\mathrm{S}$ linearly decreased (Table 2).

Leaf tissue $\mathrm{S}$ concentrations differed in response to $\mathrm{Na}_{2} \mathrm{SeO}_{4}$ concentration $(\mathrm{F}=48.55 ; P=0.0001)$, the date tissue was collected $(\mathrm{F}=20.97 ; P=0.0001)$, and the interaction of $\mathrm{Na}_{2} \mathrm{SeO}_{4}$ concentration and date $(\mathrm{F}=3.09 ; P=0.0003)$. The trend in leaf $\mathrm{S}$ accumulation with advancing sample dates depended on the $\mathrm{Na}_{2} \mathrm{SeO}_{4}$ treatment (Fig. 2). Mean leaf $S$ concentration in response to increasing tissue collection dates resulted in significant cubic trends at $0,0.5,1.0$, and $2.0 \mathrm{mg} \cdot \mathrm{L}^{-1} \mathrm{Na}_{2} \mathrm{SeO}_{4}$ concentration. At 1.5 $\mathrm{mg} \cdot \mathrm{L}^{-1} \mathrm{Na}_{2} \mathrm{SeO}_{4}$ concentration, a significant quadratic response was found.

Bulb tissue $\mathrm{S}$ concentrations differed in response to $\mathrm{Na}_{2} \mathrm{SeO}_{4}$ concentration $(F=5.04 ; P=0.0019)$ and the date tissue was collected $(\mathrm{F}=21.10 ; P=0.0001)$. Sulfur concentrations for the first two sampling dates were unavailable due to insufficient bulb tissue. Mean bulb $\mathrm{S}$ concentration in response to increasing tissue collection dates resulted in significant quadratic trends at $0,0.5$, and $1.0 \mathrm{mg} \cdot \mathrm{L}^{-1} \mathrm{Na}_{2} \mathrm{SeO}_{4}$. At 1.5 and $2.0 \mathrm{mg} \cdot \mathrm{L}^{-1} \mathrm{Na}_{2} \mathrm{SeO}_{4}$ significant linear decreases were detected over increasing dates (Fig. 3).

Sulfur accumulation in the root tissues differed in response to $\mathrm{Na}_{2} \mathrm{SeO}_{4}$ concentration $(\mathrm{F}=6.26 ; P=0.0013)$ and the date tissue was collected $(\mathrm{F}=3.82 ; P=0.03)$. Sulfur concentrations for the first two sampling dates were unavailable due to insufficient root tissue. Mean root $S$ concentration in response to tissue collection date produced a significant quadratic trend for $0.5 \mathrm{mg} \cdot \mathrm{L}^{-1} \mathrm{Na}_{2} \mathrm{SeO}_{4}$ and a significant linear trend for $1.0 \mathrm{mg} \cdot \mathrm{L}^{-1} \mathrm{Na}_{2} \mathrm{SeO}_{4}$. No statistically significant trends were found for $0,1.5$, or $2.0 \mathrm{mg} \cdot \mathrm{L}^{-1}$ $\mathrm{Na}_{2} \mathrm{SeO}_{4}$ (Fig. 4).

Sulfur is actively taken up by plants, mainly as $\mathrm{SO}_{4}{ }^{-2}$, and assimilated into cysteine. The controlling enzymes for $S$ uptake are 
S catabolic enzymes, such as aryl sulfatase, choline sulfatase, and various S permeases (Ketter et al., 1991). Uptake of $\mathrm{SO}_{4}{ }^{-2}$ and $\mathrm{SeO}_{4}{ }^{-2}$ was shown to be controlled by the same carrier with similar affinity for both ions (Leggett and Epstein, 1956). Earlier studies demonstrated an antagonistic relationship for uptake between $\mathrm{SeO}_{4}^{-2}$ and $\mathrm{SO}_{4}{ }^{-2}$ (Ferrari and Renosto, 1972; Leggett and Epstein, 1956; Mikkelsen et al. 1989). Adding $\mathrm{SO}_{4}^{-2}$ lowered $\mathrm{SeO}_{4}{ }^{-2} \mathrm{ab}-$ sorption and transport in excised barley roots. Conversely, adding $\mathrm{SeO}_{4}^{-2}$ lowered $\mathrm{SO}_{4}^{-2}$ absorption and transport. The antagonistic relationship occurred at a $1 \mathrm{SO}_{4}^{-2}: 1 \mathrm{SeO}_{4}{ }^{-2}$ ratio. At the lower $\mathrm{Na}_{2} \mathrm{SeO}_{4}$ concentrations in our study, we report a significant increase in $\mathrm{SO}_{4}^{-2}$ uptake and accumulation in leaf and bulb tissues (Table 1). The $\mathrm{SeO}_{4}{ }^{-2}$ to $\mathrm{SO}_{4}{ }^{-2}$ ratios were 1:500, 1:250, 1:150, and 1:125 for the 0.5-, 1.0-, 1.5-, and 2.0-mg. $\mathrm{L}^{-1} \mathrm{Na}_{2} \mathrm{SeO}_{4}$ treatments, respectively. In a preliminary experiment, a $1 \mathrm{SeO}_{4}^{-2}: 3 \mathrm{SO}_{4}^{-2}$ ratio resulted in onion plant death within 6 weeks. Our experiment differed from previous studies in that measurements were taken from whole plants over the entire growth cycle compared to excised roots over a 30- to 60-h period. The mechanism responsible for the observed increase in $\mathrm{SO}_{4}{ }^{-2}$ uptake in the presence of low $\mathrm{SeO}_{4}{ }^{-2}$ concentrations warrants further investigation. An interesting question would be to ask whether plant $S$ permease concentration is influenced by the concentrations of $\mathrm{SeO}_{4}^{-2}$ and $\mathrm{SO}_{4}{ }^{-2}$ in the soil solution.

We showed that onions take up and accumulate Se in proportion to available $\mathrm{Na}_{2} \mathrm{SeO}_{4}$ concentrations used in this study. We also demonstrated that onions will grow normally in the presence of $\mathrm{Na}_{2} \mathrm{SeO}_{4}$ concentrations of up to $1.0 \mathrm{mg} \cdot \mathrm{L}^{-1}$ in nutrient solutions if $\mathrm{SO}_{4}^{-2}$ concentrations are maintained at $192.3 \mathrm{mg} \cdot \mathrm{L}^{-1}$. At higher $\mathrm{Na}_{2} \mathrm{SeO}_{4}$ concentrations, however, growth was visibly depressed, yet onions bulbed and matured. Additionally, low concentrations of $\mathrm{Na}_{2} \mathrm{SeO}_{4}$ significantly enhanced $\mathrm{S}$ uptake and accumulation in onion.

\section{Literature Cited}

Adriano, D.C. 1986. Trace elements in the terrestrial environment. SpringerVerlag, New York.

Arvy, M.P. 1993. Selenate and selenite uptake and translocation in bean plants (Phaseolus vulgaris). J. Expt. Bot. 44:1083-1087.

Broyer, T.C., D.C. Lee, and C.J. Asher. 1966. Selenium nutrition of green plants. Effects of selenite supply on growth and selenium content of alfalfa and subterranean clover. Plant Physiol. 41:1425-1428.

Brown, T.A. and A. Shrift. 1982. Selenium: Toxicity and tolerance in higher plants. Biol. Rev. 57:59-84.

Bryant, R.D. and E.J. Laishley. 1988. Evidence for two transporters of sulfur and selenium oxyanions in Clostridium pasteurianum. Can. $\mathrm{J}$. Microbiol. 34:700-703.

Cai, X.J., E. Block, P.C. Uden, X. Zhang, B.D. Quimby, and J.J. Sullivan. 1995. Allium chemistry: Identification of selenoamino acids in ordinary and selenium-enriched garlic, onion, and broccoli using gas chromatography with atomic emission detection. J. Agr. Food Chem. 43:1754 1757.

Combs, Jr., G.F. and S.B. Combs. 1986. The role of selenium in nutrition. Academic Press, Orlando, Fla.

Eurola, M., P. Ekholm, M. Ylinen, P. Koivistoinen, and P. Varo. 1989. Effects of selenium fertilization on the selenium content of selected Finnish fruits and vegetables. Acta Agr. Scandinavica 39:345-350.

Ferrari, G. and F. Renosto. 1972. Regulation of sulfate uptake by excised barley roots in the presence of selenate. Plant Physiol. 49:114-116.

Freeman, G.G. and N. Mossadeghi. 1970. Effect of sulphate nutrition on flavour components of onion (Allium cepa). J. Sci. Food Agr. 21:610-615.

Furr, A.K., W.C. Kelly, C.A. Bache, W.H. Gutenmann, and D.J. Lisk. 1976. Multielemental uptake by vegetables and millet grown in pots on fly ash amended soil. J. Agr. Food Chem. 24:885-888.

Furr, A.K., T.F. Parkinson, W.H. Gutenmann, IS. Pakkala, and D.J. Lisk.
1978. Elemental content of vegetables, grains, and forages field-grown on fly ash amended soil. J. Agr. Food Chem. 26:357-359.

Gains, T.P. and G.A. Mitchell. 1979. Chemical methods for soil and plant analysis. Univ. of Georgia Costal Plain Expt. Sta. Agron. Hdbk. 1:1-105. Gupta, U.C. 1991. Boron, molybdenum and selenium status in different plant parts in forage legumes and vegetable crops. J. Plant Nutr. 14:613621.

Gutenmann, W.H. and D.J. Lisk. 1996. Increasing selenium in fieldgrown onions by planting in peat moss pots containing coal fly ash. Chemosphere 32:1851-1853.

Hoagland, D.R. and D.I. Arnon. 1950. The water culture method for growing plants without soil. Calif. Agr. Expt. Sta. Circ. 347.

Hurd-Karrer, A.M. 1937. Comparative toxicity of selenates and selenites to wheat. Amer. J. Bot. 24:720-728.

Hurd-Karrer, A.M. 1938. Relation of sulphate to selenium absorption by plants. Amer. J. Bot. 25:666-675.

Ip, C. and D.J. Lisk. 1994. Enrichment of selenium in allium vegetables for cancer prevention. Carcinogenesis 15:1881-1885.

Ip, C., D.J.Lisk, and G.S. Stoewsand. 1992. Mammary cancer prevention by regular garlic and selenium-enriched garlic. Nutr. Cancer 17:279-286.

Kabata-Pendias, A. and H. Pendias. 1992. Trace elements in soils and plants. CRC Press, Boca Raton, Fla.

Ketter, J.S., G. Jarai, Y.H. Fu, and G.A. Marzluf. 1991. Nucleotide sequence, messenger RNA stability, and DNA recognition elements of cys-14, the structural gene for sulfate permease II in Neurospora crassa. Biochemistry 30:1780-1787.

Landcaster, J.E. and M.J. Boland. 1990. Flavor biochemistry, p. 33-72. In: H.D. Rabinowitch and J.L. Brewster (eds.). Onions and allied crops. vol. 3. CRC Press, Boca Raton, Fla.

Leggett, J.E. and E. Epstein. 1956. Kinetics of sulfate absorption by barley roots. Plant Physiol. 31:222-226.

Mayland, H.F., L.F. James, K.E. Panter, and J.L. Sonderegger. 1989. Selenium in seleniferous environments, p. 15-50. In: L.W. Jacobs (ed.). Selenium in agriculture and the environment. Amer. Soc. Agron.-Soil Sci. Soc. Amer., Madison, Wis.

Mikkelsen, R.L., A.L. Page, and F.T. Bingham. 1989. Factors affecting selenium accumulation by agricultural crops, p. 65-94. In: L.W. Jacobs (ed.). Selenium in agriculture and the environment. Amer. Soc. Agron.Soil Sci. Soc. Amer., Madison, Wis.

Randle, W.M. 1992. Onion germplasm interacts with sulfur fertility for plant sulfur utilization and bulb pungency. Euphytica 59:151-156.

Randle, W.M., M.L. Bussard, and D.F. Warnock. 1993. Ontogeny and sulfur fertility affect leaf sulfur in short-day onions. J. Amer. Soc. Hort. Sci. 118:762-765.

Randle, W.M., E.B. Block, M.H. Littlejohn, D. Putman, and M.L. Bussard. 1994. Onion (Allium cepa L.) thiosulfinates respond to increasing sulfur fertility. J. Agr, Food Chem. 42:2085-2088.

Shane, B.S., C.B. Littman, L.A. Essick, W.H. Gutenmann, G.J. Doss, and D.J. Lisk. 1988. Uptake of selenium and mutagens by vegetables grown in fly ash containing greenhouse media. J. Agr. Food Chem. 36:328 333.

Shrift, A. 1954. Sulfur-selenium antagonism. I. Antimetabolite action of selenate on the growth of Chlorella vulgaris. Amer. J. Bot. 41:223-230. Shrift, A. and J.M. Ulrich. 1969. Transport of selenite and selenate into Astrogalus roots. Plant Physiol. 44:893-896.

Singh, B.R. 1994. Effects of selenium-enriched calcium nitrate, topdressed at different growth stages, on selenium concentration in wheat Fert. Res. 38: 199-203.

Steel, R.G.D. and J.H. Torrie. 1980. Principles and procedures of statistics a biometrical approach. McGraw-Hill, New York.

Trelease, S.F. and O.A. Beath. 1949. Selenium. Champlain Printers, Burlington, Vt.

Trelease, S.F., A.A. DiSomma, and A.L. Jacobs. 1960. Seleno-amino acid found in Astragalus bisulcatus. Science 132:618.

van Dorst, S.H. and P.J. Peterson. 1984. Selenium speciation in the soil solution and its relevance to plant uptake. J. Sci. Food Agr. 35:601-605. Williams, M.C. and H.F. Mayland. 1992. Selenium adsorption by twogrooved milkvetch and western wheatgrass from selenomethionine, selenocystine, and selenite. J. Range Mgt. 45:374-378. 